\title{
PHYSICAL LOAD INTENSITY IN STANDARD AND LATIN AMERICAN SPORTS DANCING PROGRAMMES FOR JUVENILE DANCERS
}

\author{
Aistė Barbora Ušpurienė, Algirdas Čepulėnas \\ Lithuanian Academy of Physical Education, Kaunas, Lithuania
}

\begin{abstract}
Research background and hypothesis. Sports dances at the contest intensity demand great athletic fitness and functional capacity from dancers We still lack research about changes in the heart rate in the group of juvenile dancers' while dancing Standard and Latin American dances. The present study aims at verifying the hypothesis that while juvenile dancers dancing contest programmes, the heart rate is changeable and can reach to $160-190 \mathrm{beats} / \mathrm{min}$ and above, sports dancers consume much energy.

Research aim was to investigate changes in the heart rate and energy consumption in the group of juvenile dancers while dancing Standard and Latin American dances.

Research methods. The research participants were 16 dancers ( 8 girls and 8 boys). The age of girls was 9.88 (0.83) years, and that of boys -9.86 (1.07) years. We established changes in the heart rate dancing Standard and Latin American dances. During continuous dancing we registered the heart rate using "Polar S 610" Heart Rate Monitor (Finland) with computer data registering system. According to the indices received from the heart rate monitor we calculated the average, maximal and minimal heart rate values and energy consumption (kcal) during the period of sports dancing programme.

Research results. The data of $\mathrm{HR}$ analysis showed that during a 10-min model practice session dancing Standard and Latin American dances, the heart rate which remains the longest is 160-190 beats/min. During Latin American dances, energy outlay for girls was greater than that for boys $(p<0.05)$, but lower compared to those when the girls danced the Standard programme.

Discussion and conclusions. In contest programmes of sports dancing, physical loads are of changing intensities and thus they have a big impact on the cardiovascular system of young dancers. At the threshold of anaerobic intensity, some moments of the dance are performed at greater intensity then the anaerobic threshold, and even critical intensity limit is reached.
\end{abstract}

Keywords Standard dances, Latin American dances, intensity of physical load, heart rate, energy consumption.

\section{INTRODUCTION}

$\mathrm{S}$ ports dancing is becoming more and more popular among children and adolescents. Even children start participating in sports dancing contests. Dace is one way of human communication, cognition and expression (Bannon, Sanderson,2000; Lavender, Predock-Linnell, 2001; Smith-Autard, 2003). Dance offers a unique and rich world of meanings and values and develops children's aesthetic and artistic experience (Banevičiūtè, 2007). Sports dancing is a sport, but it is also an art. It develops children's physical, aesthetic and musical abilities (Карпенко, Сивицкий, 2009). Dancers must be able to perform different movements, express themselves in space, express the rhythm and pace (Banevičiūtè, 2007). Movements are performed both in a locomotor way - while moving dancers move from one space to another - and in a non-locomotor way - staying in one place. Sports dances danced at the contest intensity demand good athletic fitness and functional capacity from dancers 
(Faina, Bria, 2000; Kostić et al., 2003; Klonova, Klonovs, 2010; Радионов, 2011). In sports dancing athletes perform nonstandard dynamic movements at the changeable intensity, and their performance needs the mobilization of intensive activities of the cardiovascular and respiratory systems (Ekblöm et al., 1968; Blanksby, Reidy, 1988; Faina, Bria, 2000).

In the assessment of the impact of physical load in competitive activities, we should know the peculiarities of changes in the heart rate (HR) during the practice sessions and the competitions.

There is not much research analysing changes in the heart rate of dancers of different ages when they dance sports dances.

Research aim was to investigate changes in the heart rate and energy consumption in the group of juvenile dancers while dancing Standard and Latin American dances.

\section{RESEARCH METHODS}

The research sample included 16 juvenile dancers (eight pairs of dancers). The mean age $(\bar{x}(\mathrm{SD}))$ of girls was $9.88(0.83)$ years, and that of boys $-9.86(1.07)$ years. The subjects corresponded to the mastery level of E6-D class. Some body composition indices of dancers are given in Table.

The intensity of the load during sports dancing practice was established using pulse meter "Polar S610i" (Finland). The heart rate (HR) of juvenile sports dancers was taken during the model practice sessions. We registered the heart rate at the intervals of $5 \mathrm{~s}$ and the energy outlay (kcal). The dancers performed the contest program of Standard and Latin American dances which lasted for $10 \mathrm{~min}$. Four dances were performed lasting 2 min with short breaks between them (up to $20 \mathrm{~s}$ ). In the model practice sessions the dancers had to perform the contest programme not only at a high technical level, but also very artistically.

Research data were processed using methods of mathematical statistics and Microsoft Office 2003 (Excel programme). We calculated arithmetic mean $(\bar{x})$, standard deviation (SD), the index of significance of difference $\mathrm{t}$ (Student's $t$ test), index of significance $p$, the level of significance $-95 \%$, when $\mathrm{p}<0.05$.

\section{RESEARCH RESULTS}

The body composition indices of dancers corresponded to the norms of children involved in sports (Волков, 2002).

Table. Body composition indices of juvenile sports dancers ( $\bar{x}$ (SD))

\begin{tabular}{|c|c|c|c|c|}
\hline Dancers & $\begin{array}{c}\text { Height, } \\
\mathbf{c m}\end{array}$ & $\begin{array}{c}\text { Weight, } \\
\mathbf{k g}\end{array}$ & $\begin{array}{c}\text { Body mass } \\
\text { index, } \mathbf{~ k g} / \mathbf{m}^{\mathbf{2}}\end{array}$ & $\begin{array}{c}\text { Ketle index, } \\
\mathbf{g} / \mathbf{c m}\end{array}$ \\
\hline \multirow{2}{*}{ Girls } & 141.50 & 31.13 & 15.51 & 219.46 \\
& $(6.28)$ & $(5.14)$ & $(2.08)$ & $(31.71)$ \\
\hline \multirow{2}{*}{ Boys } & 143.29 & 37.43 & 18.12 & 260.15 \\
& $(7.70)$ & $(7.32)$ & $(2.62)$ & $(43.08)$ \\
\hline
\end{tabular}

We established (Figure 1) that when four Standard sports dances were performed during the model practice session, 2 min each with short breaks between them, imitating the contest, HR increased to 189.50 (12.90) beats/min for juvenile girls dancers, and 186.75 (18.45) beats/min for boys. The mean value of the girls' HR during a 10 -min practice session was 165.45 (12.00) beats/ $\mathrm{min}$, and that of boys was 162.34 (13.22) beats $/ \mathrm{min}$.
Figure 1. Heart rate indices of juvenile sports dancers during the Standard dance contest programme

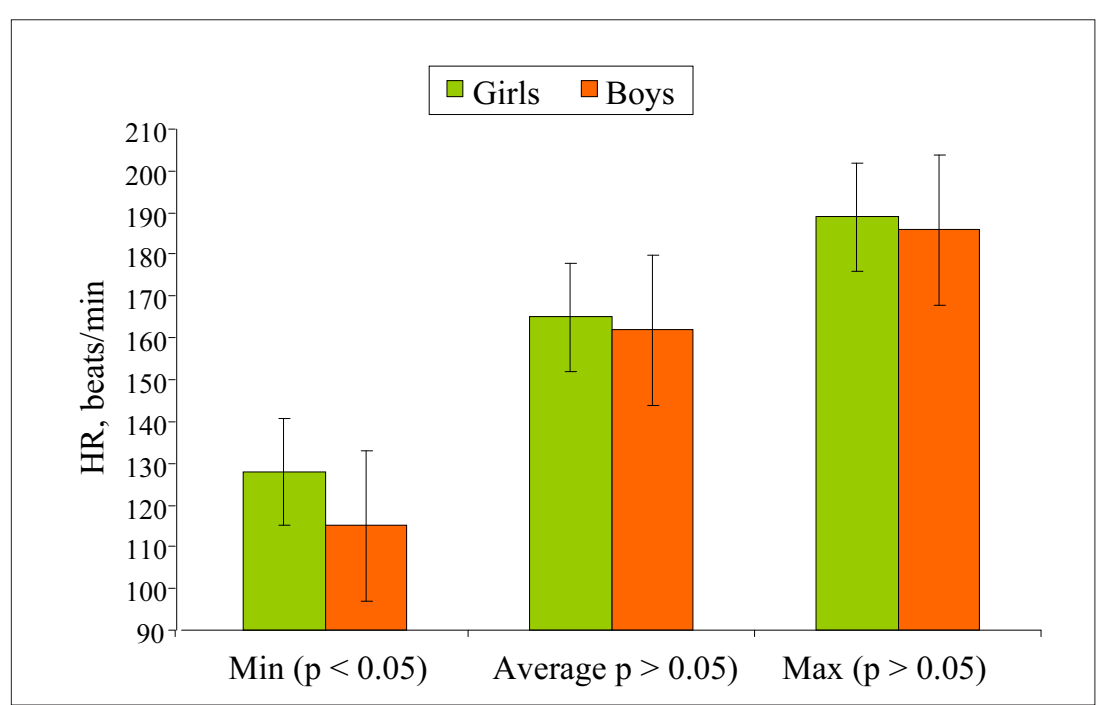


Energy outlay (Figure 2) differed during the 10-min dancing. Girls consumed 157.13(13.44) kcal, and boys - $109.22(18.45) \mathrm{kcal}$.

The data of HR analysis (Figure3) show that during a 10-min model practice session dancing Standard dances HR was between 160 beats/min and 190 beats/min.

Girls compared to boys danced with a higher heart rate. The highest percentage distribution of girls' heart rate during Standard dances was as follows: 160 beats/min - $19.25(1.07) \%$; 170 beats/ $\mathrm{min}-18.30(5.14) \%$; 180 beats $/ \mathrm{min}-21.65(7.07) \%$ and 190 beats/min - $17.85(1.17) \%$.

The highest percentage distribution of boys' heart rate was as follows: 160 beats/min -45.65
$(9.05) \% ; 170$ beats/min $-17.45(5.21) \%$ and 180 beats/min - $11.70(2.28) \%$.

During four Latin American dances, 2 min each, imitating the contest with short breaks (Figure 4), the HR values of juvenile girls increased to $188.00(16.40)$ beats $/ \mathrm{min}$, and those of boys - to 188.40 (17.11) beats $/ \mathrm{min}$. The mean HR of girls during a 10-min practice session amounted to 162.6 (16.56) beats/min, for boys it was 160.63 (17.44) beats/min.

Research (Figure 5) showed energy outlay for boys and girls in Latin American dances. Girls consumed $126.66(15.44) \mathrm{kcal}$, and boys - 109.00 (17.87) kcal.
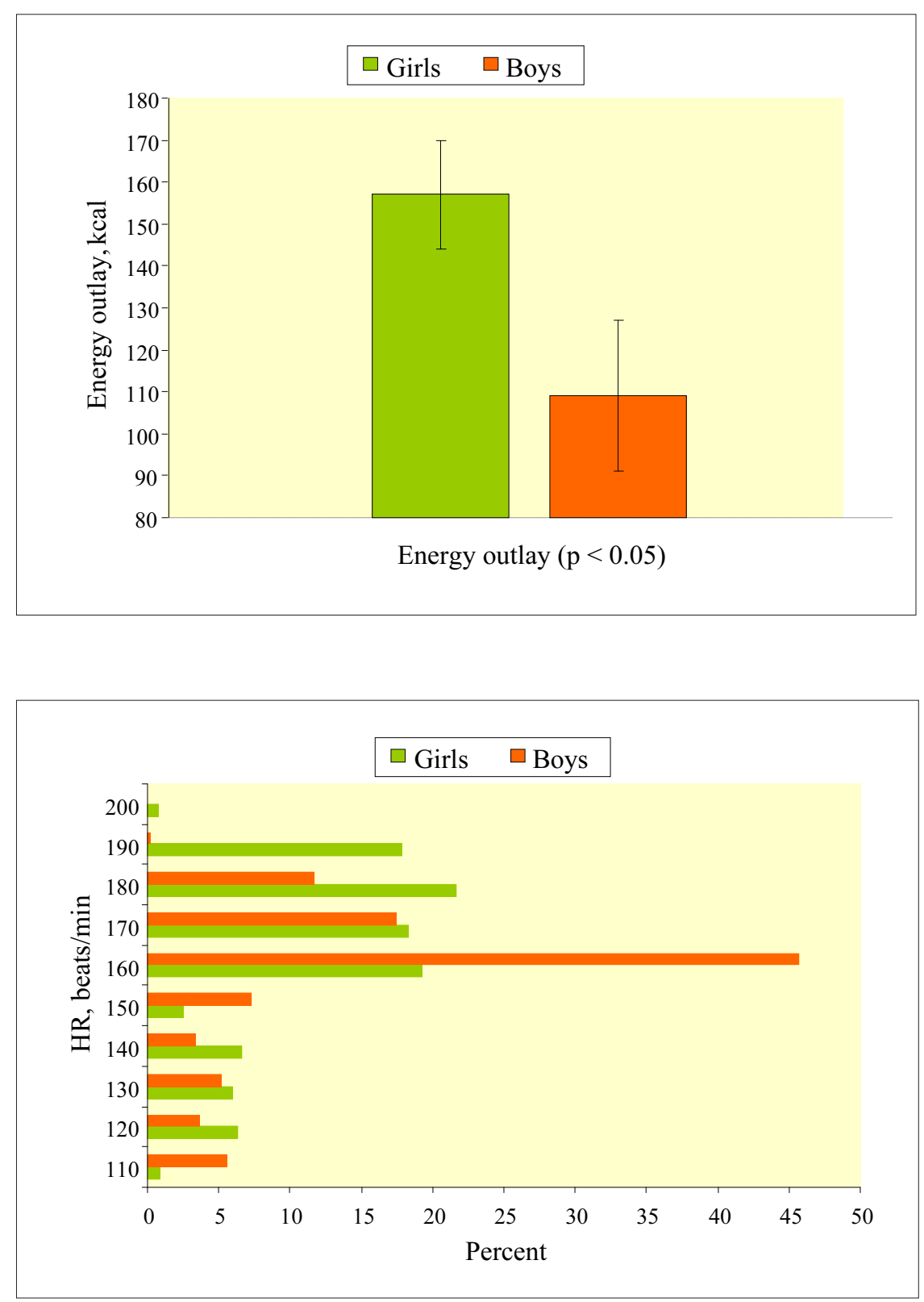

Figure 2. Energy outlay of juvenile sports dancers (kcal) during a 10-min Standard dance programme
Figure 3. Percentage distribution of juvenile sports dancers' heart rate during 10-min standard dances 
Figure 4. The indices of the heart rate for juvenile sports dancers during Latin American contest programme

Figure 5. Energy outlay (kcal) for juvenile sports dancers in Latin American dances in $10 \mathrm{~min}$
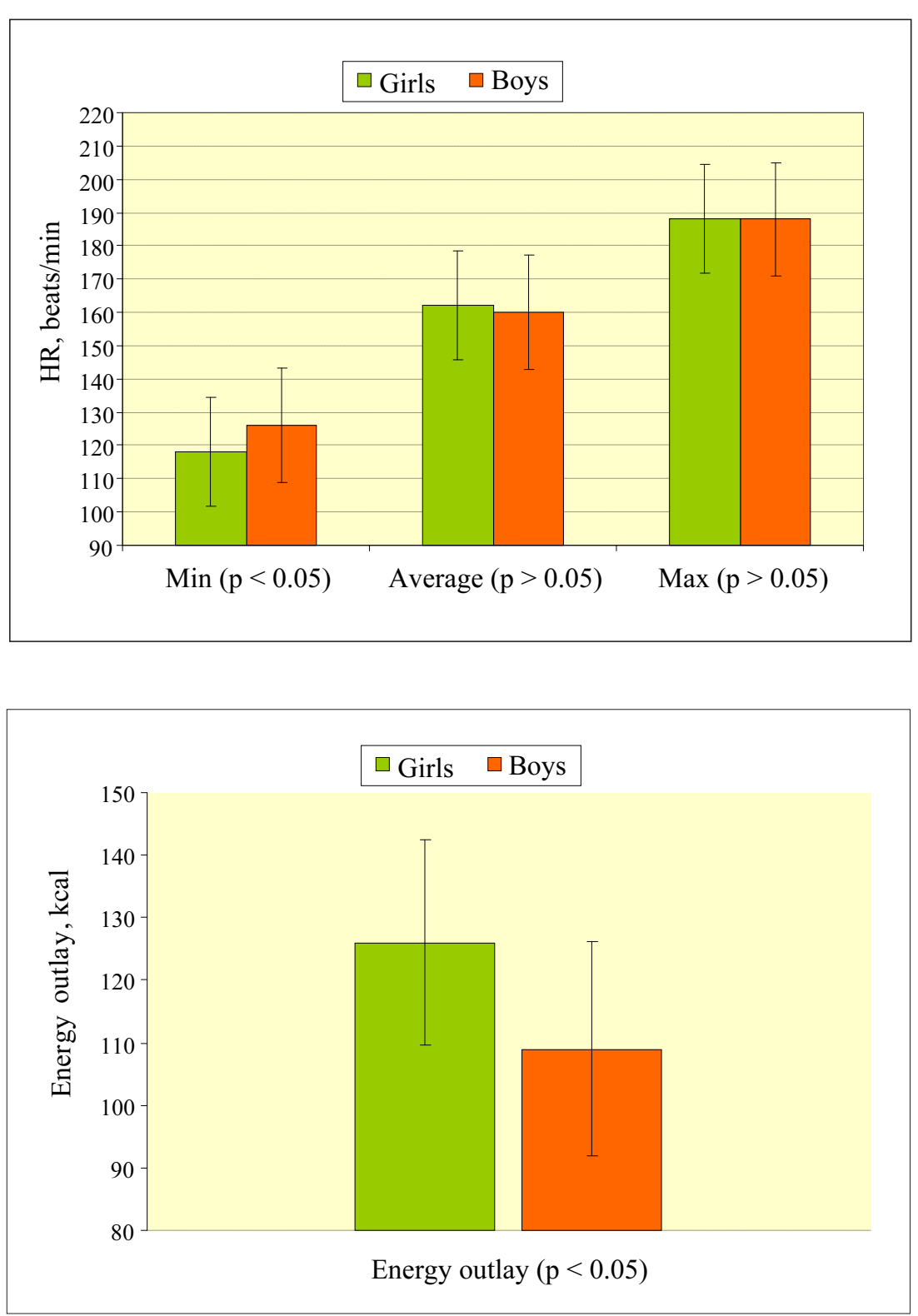

Figure 6. Percentage distribution of juvenile sports dancers' heart rate during 10 min Latin American dances

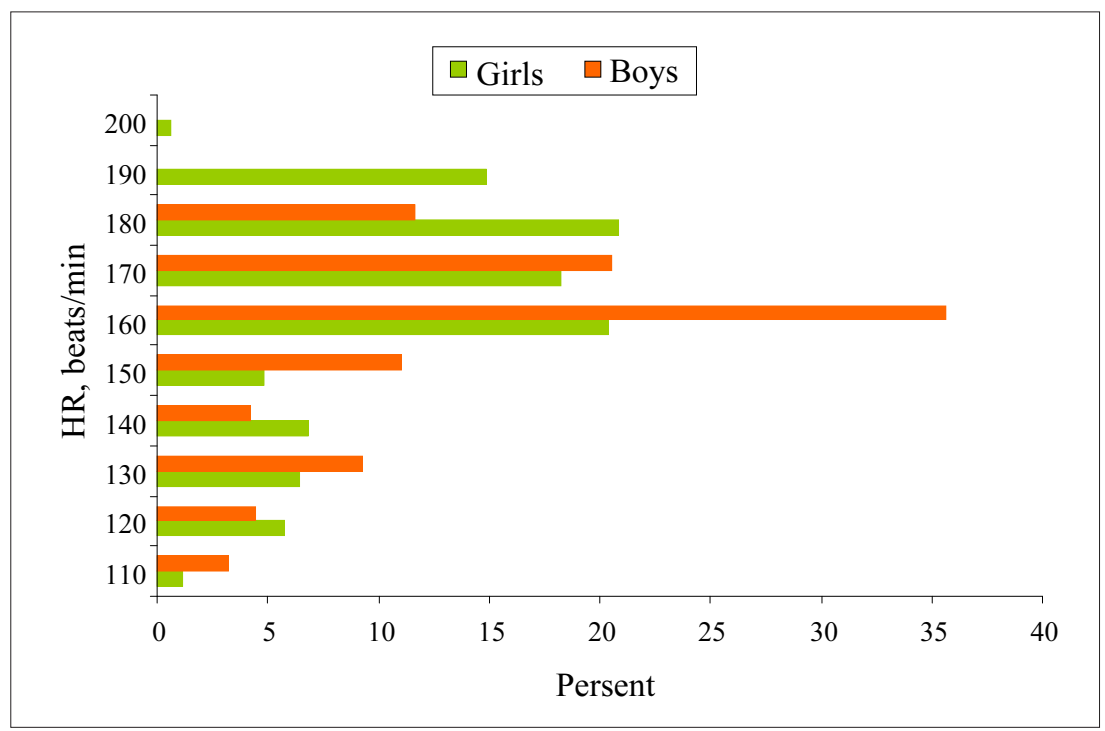


We established (Figure 6) that during a 10-min model practice session, dancing Latin American dances, the HR which remained the longest was between 150 beats/min and 190 beats/min.

Girls had higher HR values and the boys' HR values did not exceed 180 beats/min during the whole period of dancing.

The highest percentage distribution of girls' heart rate during Latin American dances was as follows: 160 beats/min $-20.40(2.14) \%$; 170 beats/ min -18.25 (4.21)\%; 180 beats/min $-20.85(8.25) \%$ and 190 beats/min $-14.90(3.15) \%$.

The highest percentage distribution of boys' heart rate was as follows: 160 beats $/ \mathrm{min}-35.60$ $(5.28) \% ; 170$ beats/min $-20.55(4.35) \%$ and 180 beats/min $-11.65(2.21) \%$.

\section{DISCUSSION}

The processes of metabolism and energy balance in sports dancing are closely related to the heart rate and oxygen supply to working muscles (Faina, Bria, 2000; Klonova, Klonovs, 2010; Vissers et al., 2011). Changes in children's heart rate during the dance show the response of their cardiovascular system to physical load. When children grow, their heart rate becomes less frequent: for 9-10-yearold children HR at rest is $76-86$ beats $/ \mathrm{min}$, for 11-12-year-old children - 78-80 beats/min (Cited from Milašius, 1997).

Children's anaerobic reactions become more active at higher HR, in contrast to adults, thus children reach anaerobic threshold at higher HR compared to adults not engaged in sports.

Researchers (Сонькин, 1978) found that 9-10-year-old children's HR ( $\bar{x}(\mathrm{SD}))$ at the anaerobic threshold amounted to $179.00(3.20)$ beats/ min and, compared to HR at rest, it increased by 94.00 (3.40) beats/min. The threshold of anaerobic metabolism is a limit where anaerobic reactions become more active in energy production with the increase in the work intensity (Skernevičius et al., 2011). Ten-year-old girls reach the critical limit of physical work intensity $\left(\mathrm{VO}_{2} \max \right)$ when their $\mathrm{HR}$ is 184.00 (13.90) beats/min, and boys - 185.00 (3.80) beats/min. Eleven-year-old boys and girls reach $\mathrm{VO}_{2}$ max limit when their heart rate is respectively 190.00 (8.40) beats/min and 185.00 (4.20) beats/ min (Гуминский, 1973).
HR of our researched juvenile sports dancers (Figures 1, 4), dancing Standard and Latin American contest programme, exceeded the limits of anaerobic threshold at some moments of the dance and reached the limit of critical intensity $\left(\mathrm{VO}_{2} \max \right)$.

Dancing a 10-min (with short breaks between dances) Standard dance programme, girls danced $77.15 \%$ of the time with the heart rate of $160-190$ beats/min, but at certain moments their heart rate amounted to 200 beats $/ \mathrm{min}$.

Boys danced $74.8 \%$ of the time with the heart rate of $160-180$ beats $/ \mathrm{min}$. Research literature (Радионов, 2011) contains evidence that during 2-min vigorous dance sports dancers consume as much energy as if they ran $20-400 \mathrm{~m}$ putting maximal efforts, and during 1 hour of practice their energy outlay is $300-400 \mathrm{kcal}$.

During a 10-min Latin American dance programme, girls danced $77.05 \%$ of the time with the heart rate of $160-190$ beats/min, (180 beats/ $\min -21.65 \%$, 190 beats/min $-17.8 \%$ ), but at certain moments their heart rate amounted to 200 beats $/ \mathrm{min}$. Boys danced $67.8 \%$ of the time with the heart rate of $160-180$ beats/min (180 beats/min $11.65 \%)$.

It has been established (Ušpurienè, Čepulènas, 2010) that during Latin American dances, the HR values of adult $\mathrm{D}$ class sports dancers reach 183.50 (11.45) beats/min for women and 182.75 (10.87) beats/min for men.

During Latin American dances, energy outlay for girls was greater than that for boys $(p<0.05)$, but lower compared to those when the girls danced the Standard programme (Figures 2, 5). During Latin American dances, women's energy outlay amounts to $43.20(3.30) \mathrm{kJ} / \mathrm{min}$., those of men $54.00(9.60) \mathrm{kJ} / \mathrm{min}$. (Blansby, Reidy, 1988).

On the basis of our research results we claim that juvenile sports dancers perform their contest programme at the intensity anaerobic threshold, higher intensity than the anaerobic threshold and reach the critical limit. During the practice sessions of juvenile sports dancers, it is very important to improve the adaptation of their body functions to physical loads corresponding to the intensity of sports contest activities. 


\section{CONCLUSIONS AND PERSPECTIVES}

In contest programmes of sports dancing, physical loads are of changing intensities and thus they have a big impact on the cardiovascular system of young dancers. At the threshold of anaerobic intensity, some moments of the dance are performed at greater intensity then the anaerobic threshold, and even critical intensity limit is reached.

\section{REFERENCES}

Banevičiūtè, B. (2007). Šokio gebejjimų raiškos ypatumai. Acta Pedagogica Vilnensia, 19, 82- 92.

Bannon, F., Sanderson, P. (2000). Every moment: Aesthetically significant dancde education. Research in Dance Education, 1 (1), 9-26.

Blanksby, B. A., Reidy, P. W. (1988). Heart rate and estimated energy expenditure during ballroom dancing. British Journal of Sports Medicine, 2 (22), 57-60.

Ekblöm, B., Astrand, P. O., Saltin, B., Stenberg, J., Wallström, B. (1968). Effect of training on circulatory response to exercise. Journal of Applied Physiology, 24 (4), 518-525.

Faina, M., Bria, S. (2000). Is dance sport a leisure/ wellness activity and/or sport? [2009 09 21]. Internet link: <http://_www.idsf.net/documents/dancesport_a sport.pdf $>$

Kḷonova, A., Kḷonovs, J. (2010). Heart rate and energy consumption during standard sport dancing. LASE Journal of Sport Science, 1 (1), 48-52.

Kostić, R., Miletić, D., Jocić, D., Uzunović, S. (2003). The Influence of Dance Structures on The Motor Abilities of Preschool Children [2009 12 02]. Internet link: <http:// www.facta.junis.ni.ac.rs/pe/pe2002/pe2002-08.pdf>

Lavender, L., Predock-Linnell, J. (2001). From improvisation to choreography: The critical bridge. Research in Dance Education, 2 (2), 195-210.

Milašius, K. (1997). Ištvermę lavinančiu sportininku organizmo adaptacija prie fiziniu krūviu. Vilnius: VPU.

Skernevičius, J., Milašius, K., Raslanas, A., Dadelienė, R. (2011). Sporto treniruote. Vilnius: VPU.
Smith-Autard, J. M. (2003). The essential relationship between pedagogy and technology in enhancing the reaching of dance form. Research in Dance Education, 4 (2), 151-169.

Ušpurienė, A. B., Čepulènas, A. (2010). Characteristics of the intensity of physical load in Latin American dances. Cпорт, стрес, адаптация. Олимпийски спорт и спорт за Всички: 5-тый международный научный конгрес (рp. 133-136). София, Бьлгария.

Vissers, D., Roussel, W., Mistiaen, W. et al. (2011). Can a submaximal exercise performance predict peak exercise performance in dancers? European Journal of Sport Science, 11 (6), 397-400.

Волков, Л. В. (2002). Теория и методика детского и юношеского спорта. Киев.

Гуминский, А. А. (1973). Возрастное развитие систем кислородного обеспечения организма и их совершенствование в процессе занятий спортом: автореферат докт. дис. Москва.

Карпенко, Л. А., Сивицкий, В. А. (2009). Базовая подготовка в спортивных танцах на паркете. Учёные записки, 5 (51), 36-40.

Радионов, М. В. (2011). Физическая подготовленность юных спортсменов-танцоров как средство повышения спортивного результата. Теория $u$ практика физической культуры, 4, 58-61.

Сонькин, В. Д. (1978). Возрастные изменения энергообеспечения мышечной деятельности. В кн. Биологический возраст и возрастная периодизация: сборник научных трудов (сс. 91-96). Москва. 


\title{
JAUNUČIŲ GRUPĖS SPORTINIŲ ŠOKIŲ ŠOKĖJŲ FIZINIO KRŪVIO INTENSYVUMO YPATUMAI ŠOKANT STANDARTINIUS IR LOTYNU AMERIKOS ŠOKIUS
}

\author{
Aistė Barbora Ušpurienė, Algirdas Čepulėnas \\ Lietuvos kūno kultūros akademija, Kaunas, Lietuva
}

\begin{abstract}
SANTRAUKA
Tyrimo pagrindimas ir hipoteze. Sportiniai šokiai, šokami varžybų intensyvumu, iš šokejjų reikalauja gero atletinio parengtumo ir funkcinio pajègumo. Tyrimu, analizuojančiu jaunučiu grupès šokèju širdies susitraukimų dažnio kaitą šokant standartinius ir Lotynų Amerikos šokius, trūksta. Tyrimu siekiama patikrinti hipotezę, kad šokant sportinius šokius varžybų intensyvumu jaunučių grupès šokejjų širdies susitraukimų dažnis gali siekti 160-190 tv./ min ir bus sunaudojama daug energijos.

Tikslas - ištirti jaunučių grupės sportiniu šokių šokẻjų širdies susitraukimų dažnio kaitą ir energijos sąnaudą šokant standartinius ir Lotynų Amerikos šokius.

Metodai. Buvo tiriama 16 šokejjų ( 8 mergaitès ir 8 berniukai). Mergaičiu amžius $-9.88(0.83)$ m., berniuku 9.86 (1.07) m. Šokant standartinius ir Lotynų Amerikos šokius varžybų intensyvumu, širdies susitraukimų dažnio kaita buvo registruojama pulso matuokliais „Polar S 610“ (Suomija) su kompiuterine duomenų registracija, taip pat analizuojamos širdies susitraukimų dažnio vidutinès, didžiausios ir mažiausios reikšmės bei energijos sąnauda (kcal) per šokių programos atlikimo laiką.

Rezultatai. Per 10 minučių modelines pratybas, šokant standartinius ir Lotynu Amerikos šokius, ilgiausiai šokama, kai širdies susitraukimu dažnis siekia 160-190 tv./min. Šokant Lotynu Amerikos šokius, mergaičiu energijos sąnauda buvo didesnè negu berniukų $(p<0,05)$, bet mažesnè negu joms šokant standartinius šokius.

Aptarimas ir išvados. Šokant sportinius šokius varžybų intensyvumu, fizinis krūvis nuolat kinta ir smarkiai veikia jaunujų šokejjų širdies ir kraujagyslių sistemą. Šokama anaerobinio slenksčio intensyvumu, atskirais šokimo momentais - didesniu intensyvumu už anaerobinio slenksčio ribą ir net pasiekiama kritinio intensyvumo riba.
\end{abstract}

Raktažodžiai: standartiniai šokiai, Lotynų Amerikos šokiai, fizinio krūvio intensyvumas, širdies susitraukimų dažnis, energijos sąnauda.

Gauta 2012 m. gegužès 2 d.

Received on May 2, 2012 